\title{
MENGUATKAN BRANDING TENUN ENDEK KHAS BULELENG MELALUI REVITALISASI PEWARNAAN DENGAN FIKSATOR NANOPASTA ANORGANIK BERBAHAN ABU VULKANIK GUNUNG AGUNG
}

\author{
I W. Karyasa', I M. A. Pradnyana ${ }^{2}$, M. V. Oviantari', I G. P. B. Astawa ${ }^{3}$ \\ ${ }^{1}$ Jurusan Kimia, FMIPA, Universitas Pendidikan Ganesha \\ 2Jurusan Teknik Informatika, FTK, Universitas Pendidikan Ganesha \\ ${ }^{3}$ Jurusan Akuntansi, FE, Universitas Pendidikan Ganesha \\ e-mail: karyasa@undiksha.ac.id, ardwi.pradnyana@undiksha.ac.id, \\ banu.astawa@undiksha.ac.id,oviantari@gmail.com
}

\begin{abstract}
Abstrak
Di era pandemi Covid-19, hampir semua industri kerajinan, termasuk kerajinan tenun endek khas Buleleng, mengalami dampak penurunan omzet penjualan yang drastis. Industri kerajinan tenun melakukan berbagai usaha penanggulangan salah satunya melalui penguatan branding industri ramah lingkungan yaitu dengan mengintensifkan pencelupan benang dengan warna alam berbahan baku lokal. Namun, masalah utama rendahnya kualitas dan daya tahan luntur warna perlu dipecahkan. Temuan terbaru tentang nanopasta anorganik fiksator warna alam merupakan salah satu solusi. Tujuan kegiatan penerapan teknologi yang dilaporkan ini adalah menguatkan branding tenun endek khas Buleleng melalui revitalisasi pewarnaan dengan fiksator nanopasta anorganik berbahan abu vulkanik Gunung Agung. Hasil penerapan teknologi pencelupan benang katun dan sutera menggunakan pewarna alam dan fiksator nanopasta anorganik menghasilkan kualitas warna, daya tahan luntur warna dan kualitas kekuatan tarik dan mulur benang hasil pencelupan yang baik. Respon mitra industri terhadap teknologi pewarnaan ini sangat baik didukung oleh respon baik dari calon pengguna produk kerajinan tenun endek khas Buleleng ini. Usaha revitalisasi teknologi pewarnaan dengan warna alam dan fikastor nanopasta anorganik berdampak pada penguatan branding dengan meningkatnya omzet penjualan tenun endek khas Buleleng.
\end{abstract}

Kata kunci: tenun endek, warna alam, fiksator, nanopasta

\begin{abstract}
In the Covid-19 pandemic era, most of craft industries, including Buleleng endek ethnical woven crafts, had an impact on sales drastically. Woven craft industries did some preventive efforts, one of them was through enhancing ecofriendly industry branding, i.e. through intensifying yarn dying using natural colors from local raw materials. However, the main problems on color quality, color fastness, tensile strength and ductile ability of
\end{abstract}


colored yarns resulted by natural dyeing should be handled. Our current finding on inorganic fixator nanopaste applied to natural colors could be as solution. The current applying technology activity reported here was aimed to enhance the branding of Buleleng endek ethnical woven crafts through revitalizing the dying process by using inorganic fixator nanopaste made from Gunung Agung's volcanic ash. The natural color dyeing technology was applied for cotton as well as silk yarn by using local color natural resources. It resulted that the yarns had better color quality, good grade color fastness and higher tensile strength and ductile ability. The industrial partner had good response on the natural dyeing technology, where it was also supported by good response from costumer candidates of the endek woven crafts. The revitalization of natural dyeing technology through applying inorganic fixator nanopaste affected the stronger branding of Buleleng endek woven crafts through enhancing the selling revenue.

Keywords: Endek weaping, natural color, fixator, nanopaste

\section{PENDAHULUAN}

Dampak dari Pandemi Covid-19 sangat terasa bagi industri kerajinan termasuk industri kerajinan tenun khas Buleleng yang salah satu sentranya ada di Desa Sinabun, Kecamatan Sawan, Kabupaten Buleleng. UKM Pertenunan Artha Dharma merupakan salah satu usaha industri kerajinan tenun yang telah menjadi andalan Kabupaten Buleleng dalam melestarikan dan mengembangkan kerajinan tenun khas Buleleng (Ariasa, 2020). Usaha pertenunan Artha Dharma berdiri tahun 2002 untuk melestarikan budaya menenun yang ada di desa ini karena semakin hari animo masyarakat untuk terjun menjadi penenun kian menurun (Wibisono, 2020). Usaha pertenunan Artha Dharma berkembang dengan pesat berkat bantuan dan pembinaan berbagai pihak baik pemerintah, perguruan tinggi dan pihak-pihak terkait lainnya dengan rajinnya pendiri usaha ini yaitu Ketut Rajin mengikuti berbagai pameran seperti Pesta Kesenian Bali (PKB), Denpasar Festival, Buleleng
Festival, dan sebagainya. Berbagai penghargaan juga telah diraih oleh Pertenunan Artha Dharma di antaranya adalah Juara 1 katagori desain tenun ATBM (alat tenun bukan mesin) Cagcag pada ajang lomba tenun dan songket (21-23 Juni 2017) serangkaian PKB ke-39 tahun 2017 di Taman Budaya Denpasar (Rhismawati, 2017). Pada masa pandemi ini, Pertenunan Artha Dharma tetap berproduksi, namun mengalami gejolak usaha jika dilihat dari aspek produksi, pemasaran, dan manajemen usaha dibandingkan dengan masa sebelum pandemi. Pada masa pandemi sejak Januari 2020 hingga Juli 2020, produksi kain endek mengalami penurunan hingga kira-kira $80 \%$ dibandingkan 6 bulan tahun sebelumnya dengan jumlah pekerja masih sekitar 20 orang yang sebelum pandemi 50 orang. Hal ini berdampak banyak peralatan produksi seperti alat tenun semi mesin dan alat tenun bukan mesin yang menganggur. Hambatan akibat pandemi terkait ketersediaan bahan baku benang dan warna sintetik (warna 
basis dan warna rapid beserta bahan kimia tambahan) menyebabkan peningkatan harga yang berakibat pada penambahan biaya produksi. Namun demikian, penggantian warna sintetk dengan warna alam masih menyisakan beberapa permasalahan diantaranya adalah sifat-sifat ketahanlunturan yang rendah terhadap pencucian, sinar matahari, dan gosokan fisik (Ado et al., 2015; Kanchana et al., 2013). Hal ini perlu dicarikan solusi yang tepat, salah satunya adalah menggunakan fiksator nanopasta seperti yang ditemukan oleeh Karyasa, dkk (2019). Ditinjau dari aspek pemasaran, sebagai akibat dari pandemi Covid-19, perolehan omzet pemasaran tenun endek khas Buleleng yang diproduksi oleh Pertenunan Artha Dharma mengalami penurunan yang drastis. Omzet pemasaran pada tahun 2019 dengan rerata mencapai Rp. 200 juta lebih/bulan, saat masa pandemi ini menurun hingga masih tinggal 10-15\% sehingga cash-flow perusahaan mengalami masalah. Hal ini diperparah oleh banyaknya pesanan kain tenun yang dibatalkan. Hal ini berdampak pada banyaknya stok hasil kerajinan tenun endek yang mengendapkan modal usaha. Di samping itu, Ketut Rajin juga menuturkan pentingnya memiliki daya ungkit yang besar dalam membangkitkan kembali usaha pertenunan ini salah satunya adalah penguatan branding kerajinan yang ramah lingkungan dengan merevitalisasi pewarnaan alami yang sedang mulai diminati berbagai kalangan.
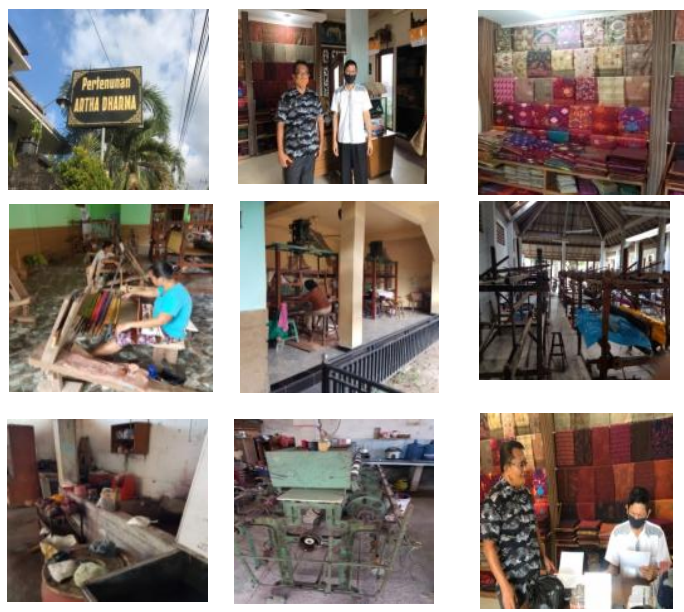

Gambar 1 Foto-foto Kondisi Terkini Usaha Pertenunan Artha Dharma

Tujuan dari kegiatan ini adalah membangun dan mengoperasikan instalasi pencelupan warna alam dengan teknologi fiksator nanopasta anorganik yang terpadu dengan instalasi pengolahan limbah pencelupan sehingga menghasilkan brand image ramah lingkungan

\section{METODE}

Kegiatan pengabdian kepada masyarakat ini menggunakan pendekatan partisipatori dengan metode penerapan ilmu pengetahuan dan teknologi tentang penggunaan nanopasta fiksator anorganik dalam proses pencelupan benang katun dan sutera menggunakan pewarna alam berbahan baku lokal. Tahapan kegiatan yang telah dilakukan adalah membangun instalasi pencelupan yang dipadukan dengan pengolahan limbahnya; (2) membuat nanopasta fiksator warna alam dari abu vulkanik Gunung Agung, nanosilika abu sekam padi dengan penambahan bubuk tunjung (ferrosulfat) atau bubuk terusi 
(kuprisulfat) dengan komposisi tertentu seperti yang dilaporkan sebelumnya (Karyasa, 2020); (3) menyiapkan pewarna alam dari bahan lokal seprti warna hijau daun mangga dan warna kuning kunyit; (4) melakukan demonstrasi proses pencelupan dan pengolahan limbahnya; (5) melakukan pendampingan kepada karyawan Pertenunan Arta Dharma untuk melakukan ulang pencelupan hingga semua benang dicelup sesuai kebutuhan, (6) menggunakan hasil pencelupan untuk proses selanjutnya dalam tahapan penenunan hingga menghasilkan kain tenun endek sesuai desain; (7) meminta respon pengguna teknologi (mitra industri) terkait proses dan hasil pencelupan, dan (8) meminta respon beberapa calon pembeli dari kain endek khas Buleleng yang dihasilkan.

\section{HASIL DAN PEMBAHASAN}

Teknologi pencelupan warna alam dengan fiksator nanopasta anorganik untuk merevitalisasi teknologi pencelupan benang bahan tenun endek khas Buleleng merupakan sebuah teknologi proses pewarnaan benang katun atau benang sutera dengan menggunakan pewarna alam dari bahan baku lokal seperti daun mangga yang melimpah keberadaannya di lingkungan sekitar, meggunakan fiksator warna alam yang berupa nanopasta dari abu vulkanik Gunung Agung, nanosilika abu sekam padi dan bahan tambahan mineral tunjung atau ferrosulfat dan mineral terusi atau kuprisulfat. Tidak seperti proses pencelupan benang menggunakan warna alam sebelumnya (yang biasa dilakukan oleh industri tenun endek khususnya di Pertenunan Artha Dharma, proses pencelupan dengan teknologi ini dimungkinkan menggunakan (a) teknik postmordanting artinya setelah benang dicelupkan ke larutan warna alam baru difiksasi dalam nanopasta fiksator lalu dibilas dalam air bersih dan diulang berkali-kali (biasanya maksimum 10 kali) hingga diperoleh warna benang yang jenuh atau tidak berubah lagi, dan (b) simulataneous mordanting dilakukan dengan mencampurkan larutan jenuh warna alam dalam keadaan panas dengan nanopasta fiksator, kemudian benang dicelupkan dan membilas-bilas langsung dalam campuran tersebut hingga diperoleh warna benang yang tidak berubah lagi baru dibilas dengan air bersih, dilakukan pengulangan jiak warna benang menurun kejenuhannya atau berubah lagi saat dibilas air bersih tersebut, pengulangan biasanya dua sampai kali lagi hasilnya tidak ada perubahan warna lagi pada benang hasil pencelupan.

Pembelajaran berharga yang diperoleh dari penerapan teknologi di industi pertenunan ini adalah penerapan teknologi pencelupan warna alam dibantu fiksator nanopasta anorganik dengan teknik pertama (postmordanting yang berulang-ulang) ternyata berguna untuk memilih gradasi warna (kejenuhan warna yang berbeda secara gradatif tetapi jenis kromanya sama sepeti contohnya warna hijau lumut gelap, hijau lumut agak gelap, hijau lumut, hingga hijau lumut terang) dengan memberhentikan pengulangan pada saat gradasi warna yang kita inginkan tercapai. Oleh karena itu diperlukan padanan warna sesuai 
desain produk sebagai alat mengecek kesesuaian warna yang kita peroleh dari pengulangan pencelupan tersebut dengan warna sesuai desain produk. Pemadanan warna ini dapat menggunakan selembar kertas yang sudah diwarnai atau secuplik kain yang telah dicelup sebelumnya saat perancangan warna produk. Pembelajaran kedua dari penerapan teknologi pencelupan menggunakan warna alam dan fiksator nanopasta anorganik teknik kedua (simultaneous mordanting) adalah pencampuran larutan warna dan nanopasta fiksator akan menjadikan warna lebih pekat terikat pada nanopasta dan langsung terfiksasi saat bersentuhan dengan serta benang, hal ini ternyata memiliki peluang mengatasi kesulitan dalam mencatri (memoleskan warna pada tahap pewarnaan kedua tenun ikat atau endek dengan desain rumit). Kalau masih menggunakan pencelupan menggunakan larutan fiksator maka waran kurang pekat dan banyaknya pelarut memungkinkan membasahi dinding atau pinggiran penghalang (ikatan dengan tali rapia pada desain tenun ikat). Paparan hasil dan pembahasan untuk setiap tahapan yang telah dilakukan dalam kegiatan penerapan teknologi ini disajikan dalam beberapa paragraph berikut.

Tahap 1 seperti pada Gambar 2, instalasi pencelupan yang dipadukan dengan pengolahan limbah pencelupan tidak mengubah lay-out produksi yang berarti karena tempat pencelupan cukup luas dan instalasi pengolahan limbah sebelumnya dapat dimanfaatkan dengan hanya menambahkan elektroda karbon yang dialiri listrik untuk mengendapkan zat warna sisa pencelupan. Ternyata, penggunaan nanopasta mampu mengikat sisa warna menjadi lumpur karena nanopasta memiliki komponen pengikat warna yang baik. Hasil pengolahan limbahnya dengan penambahan mikroba efektif (seperti EM4) dapat menjadikan limbah pencelupan warna alam lebih mudah menjadi pupuk.

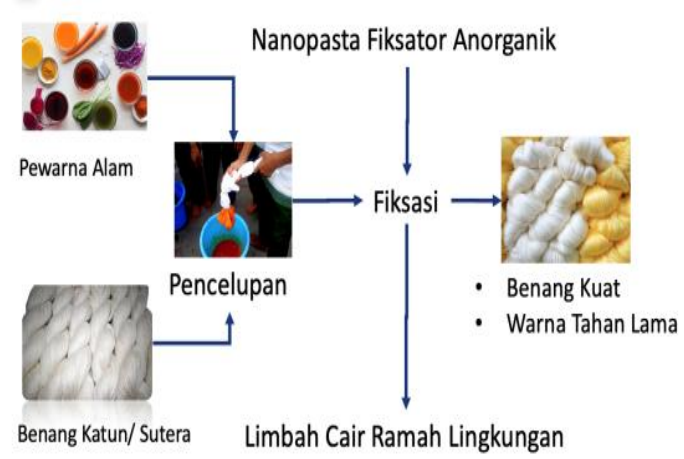

Gambar 2, Skema Instalasi Pencelupan Terpadu dengan Pengolahan Limbahnya.

Tahap 2, nanopasta fiksator warna alam belum bisa langsung dibuat di tempat mitra industri, tetap menggunakan fasilitas yang ada di laboratorium dengan jumlah terbatas. Oleh karena itu, jika penggunaan nanopasta fiksator warna alam ini semakin banyak dan masif, ada peluang untuk mendirikan usaha baru dengan memanfaatkan hasil inovasi ini.

Tahap 3, warna alam dari bahan lokal, yang keberadaannya melimpah di sekitar kita seperti daun mangga, dapat dibuat secara langsung (direct) saat akan digunakan dalam pencelupan, dengan cara mencincang dan memblender daun mangga segar lalu merebus dan menyaring hasil rebusan tersebut sehingga diperoleh larutan 
warna tanpa banyak pengotor dari sisasisa biomassa daun mangga. Larutan warna tersebut siap digunakan untuk proses selanjutnya. Cara kedua adalah menyiapkan zat warna alam secara tidak langsung artinya zat warna tersebut dibuat dalam bentuk sediaan, baik berupa bubuk warna alam maupun pasta warna alam. Hal ini dilakukan jika bahan baku keradaannya hanya di tempat-tempat tertentu atau ketersediaannya pada musim-musim tertentu seperti pewarna alam dari kulit buah manggis yang ketersediaannya tergantung musim.

Tahap 4, pelatihan dan pendampingan penerapan teknologi pencelupan menggunakan warna alam dan fiksator nanopasta anorganik diawali dengan melakukan demonstrasi proses pencelupan di hadapan para pekerja pencelupan yang ditugaskan oleh pemilik Pertenunan Artha Dharma langsung di lokasi instalasi yang telah disiapkan sebelumnya. Partisipan memperhatikan secara seksama proses dari awal hingga akhir dan di sela-sela proses tersebut partisipan dapat bertanya jawab dengan tim pelaksana.

Kemudian pada tahap 5, partisipan diajak bersama-sama melakukan proses pencelupan, dimana tim pelaksana membimbing, mendampingi dan memberikan koreksi jika ada tindakan dalam proses tersebut kurang tepat. Kalau partisipan telah memahami dan bisa melakukannya sendiri, partisipan diberikan kesempatan secara mandiri dan berkelompok melakukan proses pencelupan.

Pada proses pelatihan dan pendampingan (tahap 4 dan 5) pencelupan ini ditemukan titik krusial yaitu sampai kapan pengulangan dihentikan dan bagaimana menentukan proses membilas terakhirnya hingga tidak ada sisa nanopasta menempel sebagai debu nantinya di permukaan serat benang. Titik krusial lainnya adalah pengetahuan tentang apa yang terjadi antara zat warna dengan serat benang, dan antara zat warna dan serat benang dengan fiksator sebaiknya dipahami dan dapat dikomunikasi dengan bahasa sederhana oleh partisipan. Proses pencelupan dilakukan dalam keadaan panas agar proses penyebaran (dispersi) zat warna ke bagian-bagin serat benang berlangsung dengan baik dan dilanjutkan pengikatan gugusgugus auksokrom zat warna dengan gugus-gugus pengikat warna dari serat benang. Setelah hal itu terjadi maka benang yang telah berwana tersebut dibilas-bilaskan ke dalam nanopasta yang telah disiapkan sebelumnya. Fiksator ini berfungsi memperkuat ikatan antara zat warna dengan serat benang. Zat warna daun mangga yang berwarna hijau umumnya adalah klorofil-A dan klorofil-B dengan struktur kimia dimana pusatnya berupa ion magnesium yang terikat pada empat atom nitrogen dari kerangka strukturnya. Ion magnesium tersebut dapat disulih oleh ion-ion polivalen (seperi ion ferro atau ion kupri) yang lebih kuat daya ikat koordinatifnya dengan atom-atom nitrogen dalam kerangka strukur klorofil, kemudian ionion polivalen ini dapat membuat ikatan jembatan antara zat warna dengan serat-serat benang, ikatan ini lebih kuat dari daya tarik molekul air sehingga warna yang telah terikat pada serat 
benang tersebut sulit bisa dtarik lagi.oleh molekul air.

Pada tahap 6, benang hasil pencelupan warna alam sebelum diserahkan ke proses selanjutnya dilakukan uji mutu terkait dengan padanan warnanya sesuai desain, kedua kualitas kilap warna dan kerataan serat benang terwarnai dengan homogen dengan membanding-bandikan untaian-untaian benang di atas kertas putih. Alahkah baiknya diuji secara berkala hasil pencelupan menggunakan Standar Nasional Indonesia terkait mutu benang untuk dipintal menjadi kain. Karena bahan, proses, dan kondisi yang digunakan sudah sama dengan hasil pengujian di lingkungan relevan dan sebenarnya dari hasil pencelupan benang katun menggunakan pewarna hijau daun mangga dan komposisi nanopasta fiksator (Karyasa, 2020) yang sama maka hasil pengujian tersebut dapat sebagai rujukan. Hasil pengujian tersebut menunjukkan bahwa hasil pencelupan benang katun menggunakan pewarna alam hijau daun mangga menunjukkan kualitas warna yang baik, komposisi nanopasta dengan bahan tambahan tunjung tampilan warnanya lebih gelap dibandiingkan dengan menggunakan bahan tambahan terusi. Sedangkan sifat-sifat tahan luntur warna terhadap pencucian sabun dan sinar matahari kedua fiksator mengahsilkan kualitas yang baik. Ternyata pewarnaan dengan warna alam hijau daun mangga dengan kedua jenis fiksator terebut menghasilkan kekuatan tarik dan mulur yang lebih baik dibandingkan benang yang tanpa dicelup maupun benang yang dicelup tanpa fiksator. Hal ini memberikan keyakinan bahwa proses selanjutnya dari tahapan menjadikan benang berwarna tersebut sebagai kain endek dapat dilanjutkan. Gambar 3 menunjukkan hasil pencelupan benang katun dengan pewaran alam hijau daun mangga dengan menggunakan fiksator nanopasta dengan bahan tambahan terusi yang sudah diikat selanjutnya proses pewarnaan kedua atau proses catri, dimana campuran pasta warna alam dan nanopasta fiksator memiliki potensi sangat baik digunakan untuk mengatasi kelemahan proses catri saat ini yang belum memungkinkan menggunakan warna alam dengan hasil yang memuaskan.

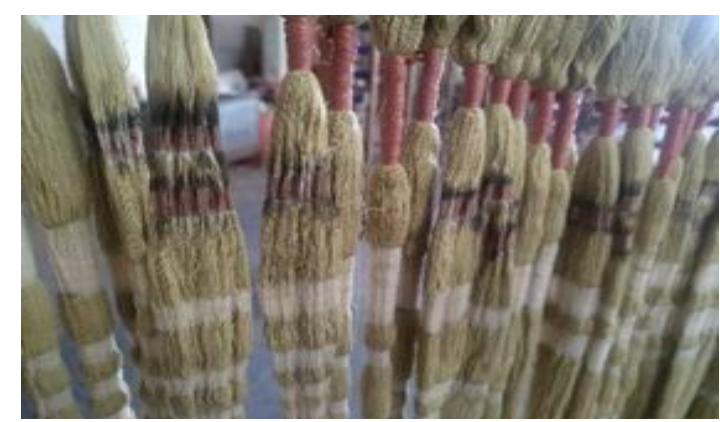

Gambar 3. Hasil Pencelupan Benang Katun dengan Warna Alam Hijau Daun Mangga dan Fiksator Nanopasta dengan Bahan Tambahan Terusi (Kuprisulfat).

Tahap ke-7, respon yang sangat baik diberikan oelh mitra industri dalam hal ini Ketut Rajin dari Pertenuan Artha Dharma, Pertama, proses pencelupan itu sendiri dapat digunakan sebagai atraksi wisata edukasi dan sebagai paket pelatihan pewarnaan alam terhadap benang sutera dan katun yang merupakan salah satu materi pelatihan kepada calon-calon pengusaha industry tenun ikat (endek) 
dan songket di Nusantara. Kedua, ada harapan memebrikan efisiensi dalam proses pencelupan dengan kualitas hasil pencelupan yang memiliki keunggulan dibandingkan menggunakan pewarna sintetik, dan ketiga, perlu adanya usaha produksi warna alam baik dalam bentuk bubuk maupun pasta dan produksi nanopasta fiksatornya, karena setiap warna alam dari jenis tumbuhan atau bagian tumbuhan yang berbeda memerlukan jenis atau komposisi fikastor yang berbeda, dan akan menjadi usaha komplementer dari usaha kerajinan tenun dan songket bahakan batik.

Tahap ke-8, respon pengunjung galeri yang memajang aneka kerajinan endek menggunakan warna alam dengan fiksator nanopasta ini adalah sebagai berikut. Dari 12 pengunjung yang diwawancarai, ada 9 orang yang sangat menyukai produk tenun endek warna alam yang difiksasi menggunakan fiksator nanopasta, 2 orang menyatakan puas dan sisanya menyatakan kurang puas karena masih mempertanyakan keberlangsungannya karena produksi nanopasta fiksator saat ini masih terbatas.

Dampak dari penguatan branding endek Bali yang salah satunya disumbangkan oleh adanya penerapan teknologi pencelupan benang menggunakan warna alam dan fiksator nanopasta anorganik dapat dilihat dari perkembangan omzet penjualan dari Pertenunan Artha Dharma yang telah menerapkan teknologi ini sejak September 2020. Gambar 4 menunjukkan bahwa terjadi peningkatan penjualan yang sangat signifikan di masa pandemi antara bulan September ke bulan Oktober
2020, di mana titik nadir penjualan saat bukan Mei 2020.

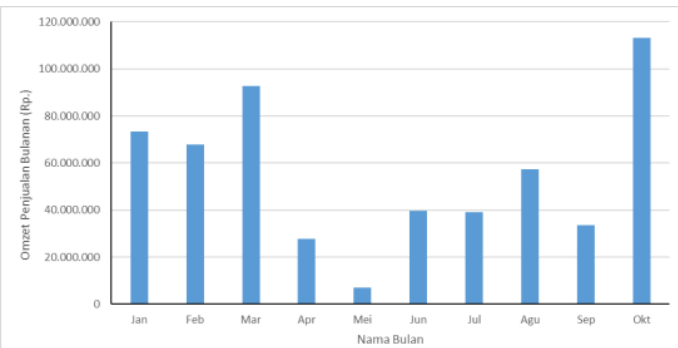

Gambar 4. Perkembangan Omzet Penjualan Tenun Endek Pertenunan Artha Dharma di Tahun 2020

\section{KESIMPULAN}

Penerapan inovasi teknologi pencelupan benang dengan pewarna alam berbahan baku lokal dan menggunakan fiksator nanopasta anorganik yang terbuat dari abu vulkanik Gunung Agung, nanosilika abu sekam padi dan bahan tambahan bubuk tunjung atau terusi tidak saja mampu meningkatkan kualitas warna dan tahan luntur warna dari benang hasil pencelupan tetapi juga meningkatkan kualitas kekuatan tarik dan mulur benang sehingga proses penenunan dapat dilakukan dengan lebih baik tanpa terganggu oleh kekhaawatiran benang putus ataupun hasil akhir kain yang mudah pudar warnanya. Revitalisasi pencelupan warna alam memberikan harapan branding tenun endek khas Buleleng lebih menguat karena keunggulan kompetitif kualitas warna, daya tahan luntur warna serta keunggulan komparatif yaitu lebih ramah lingkungan dengan biaya produksi lebih murah, di samping keunikan motif khas Buleleng. 


\section{UCAPAN TERIMA KASIH}

Penghargaan dan ucapan terima kasih disampaika kepada Direktorat Riset dan Pemberdayaan Masyarakat, Direktorat Jenderal Penguatan Riset dan Pengembangan, Kementerian Riset dan Teknologi/BRIN atas dana Hibah Pemberdayaan Masyarakat UKM Indonesia Bangkit Tahun 2020. Ucapan terima kasih juga disampaikan kepada Pertenunan Artha Dharma di Desa Sinabun, Kecamatan Sawan Kabupaten Buleleng Propinsi Bali dan LPPM Universitas Pendidikan Ganesha.

\section{DAFTAR PUSTAKA}

Ado A., Yahaya H., Kwalli A. A., Abdulkadir R. S. 2014. Dyeing of Textiles with Eco-Friendly Natural Dyes: A Review. International Journal of Environmental Monitoring and Protection. 1(5): 76-81.

Ariasa, A. 2019. Membagkitkan, Endek dan Songket Buleleng. https://disnaker.bulelengkab.go.id /berita/membagkitkanendek-dansongket-buleleng-61

Kanchana R., Fernandes A., Bhat B., Budkule S., Dessai S., Mohan R. 2013. Dyeing Of Textiles With Natural Dyes - An Eco-Friendly Approach. International Journal of ChemTech Research. 5(5): 2102-
2109.

Karyasa, I W. Suryaputra, I G N, Mardhana, I B P. 2019. Pengembangan Nanomaterial Fiksasi Dari Lumpur Nunleu Untuk Pewarnaan Alami Tenun Ikat. Laporan Penelitian. Singaraja: LPPM Undiksha.

Karyasa, I W. 2020. The Effect of Various Mass Compositions of Fixator Nanopastes on Colour, Fastness and Mechanical Properties of Cotton Yarns in Natural Green Colour Dyeing Using Mangos Leaves Extract. International Conference on Natural Sciences, Mathematics, Applications, Research and Technology (ICON-SMART), Universitas Sam Ratulangi, 2223 October 2020.

Rhismawati, N. L. 2017. Belasan Perajin Tampilkan Karya Terbaik di PKB. Antara News Bali. 24 Juni 2017. https://bali.antaranews.com/berita /107828/belasan-perajintampilkan-karya-terbaik-di-pkb

Wibisono, A. 2020. Artha Dharma Kluster Binaan BI Tampilkan Pesona Tenun Khas Buleleng. Patroli Post. 11 Januari 2020. https://www.patrolipost.com/1923 3/artha-dharma-kluster-binaan-bitampilkan-pesona-tenun-khasbuleleng/ 